\title{
Urban Commerce and Protected Cultural Landscape
}

\author{
María Griñán Montealegre *,† and Mónica López Sánchez *,t (D) \\ Department of History of Art, University of Murcia, 30001 Murcia, Spain \\ * Correspondence: mariagri@um.es (M.G.M.); monica.lopez.san@gmail.com (M.L.S.); \\ Tel.: +34-868-88-7770 (M.G.M.) \\ + Both authors contributed equally to this work.
}

Received: 30 October 2018; Accepted: 30 December 2018; Published: 4 January 2019

\begin{abstract}
By analyzing the urban landscape, this investigation focuses on some commercial typologies that exist in historical urban areas and its relationship with the urban landscape and its heritage values. Trade plays an essential role in historical urban areas, both in the past and in the present, since it is part of the urban landscape-creating it and modifying it, but also preserving it. Historical protected urban areas contain diverse elements reflecting the impacts of commercial activities that have existed in cities throughout history. At present, the urban landscape of commercial activity is made up of a multiplicity of typologies and formats which interact with the historical landscape and its values, using them to strengthen its strategies of attraction, differentiation, and sales. Shop owners contribute to the preservation of historic urban areas by maintaining the commercial functions within them. Therefore, we affirm that the role of commercial activity in the preservation of urban protected areas is essential. However, further research is needed because this aspect has not been addressed in depth by the scientific community specializing in the management of cultural heritage.
\end{abstract}

Keywords: urban commerce; cultural landscape; historic city; cultural heritage; management

\section{Introduction}

The transformations brought about by the Industrial Revolution triggered the evolution of the conservative concern-from the isolated monument to historic areas-coinciding with what Françoise Choay called the conquest of the disciplinary status of the conservation of historical monuments [1]. This was a process that was shaped during the first half of the 20th century, and ultimately consecrated in the 1960s, as a consequence of the restoration of numerous urban areas following the devastation caused by the two world wars.

From this period onwards, the milestones that were to establish the doctrine of cultural heritage in relation to the city, and the consequent task of preserving the values that make it worthy of that condition, began to occur. The notion of a protected urban landscape was established by the jump from the isolated monument to the historic area; although, it was already implicit in the concept of setting of a monument. An international definition of setting is included in the Xi'an Declaration on the Conservation of the Setting of Heritage Structures, Sites and Areas [2].

The historic urban landscape has been defined by UNESCO as "the urban area understood as the result of a historic layering of cultural and natural values and attributes, extending beyond the notion of "historic centre" or "ensemble" to include the broader urban context and its geographical setting" [3] (article 8).

The broader context "includes notably the site's topography, geomorphology, hydrology and natural features, its built environment, both historic and contemporary, its infrastructures above and below ground, its open spaces and gardens, its land use patterns and spatial organization, perceptions and visual relationships, as well as all other elements of the urban structure. It also includes social and 
cultural practices and values, economic processes and the intangible dimensions of heritage as related to diversity and identity" [3] (article 9).

Trade is among social and cultural practices and economic processes. The need for the supply and exchange of goods that occurs in every human agglomeration has motivated, throughout history and until now, the continued presence of commercial activity in the focal areas of urban social activity [4].

The routes generated by the flow of goods and services have impacted upon the emergence, flourishing, and decay of numerous urban centres throughout history $[5,6]$, while also allowing contact between cultures, beliefs, and different systems of organization [7-9]. Therefore, commercial activity is an essential functional element both in the history of the city and in its present.

Since antiquity, commercial facilities have been located in the vicinity of palaces and temples [10-12], next to the gates of cities, and near ports. These thematic facilities, sometimes made up of temporary structures, were complemented by shops installed on the ground floor of residential buildings, usually with direct access from the street. These facilities have been present in urban growth processes and, sometimes, they were determinant in these processes, as was the case during the 16th and 17th centuries, or since the middle of the 20th century [13-16].

The profound changes that have taken place since the 19th century-derived from the new economic model, technical development, the increase in urban population, and the transformations that took place within cities-would give increasing importance to commercial activity [17].

This activity would experience permeability to aesthetic fashions like never before, thanks to the development of interior and exterior design, shop windows, and advertising [17,18]. In parallel, there appeared new architectural typologies for commercial use, such as passageways or department stores $[19,20]$. The functional hierarchy of commercial facilities that has determined their location since the mid-19th century would continue to develop to the present day [21].

These tendencies that began in the 19th century would be accentuated in the 20th century, ultimately determining urban transformations [22,23]. In those tendencies, the importance of commercial activity would increase, placing it at the heart of the new models of urban growth that began to develop in the United States in the first half of the century [24]. These models pursued the perfect commercial city and materialized as residential areas in the suburbs, whose centre of community life is the shopping centre [25].

The appearance and development of the typology of the shopping centre-a symbol of the consumer society of the 20th century - and the role granted by urbanism to this entity, would set the rhythm between central urban trade and peripheral trade that would be a constant throughout the century $[22,24]$.

The 20th century would end with a concept of the city where commercial leisure activities, along with recreational and cultural activities, played a leading role in urban life [25].

In the elapsed years of the 21st century, there has been a global expansion of the peripheral commercial area typology, especially in Asia and the Middle East [26], as well as in ex-communist European countries.

At the same time, in the United States, symptoms have been produced that we are in a post-mall era in sense of shopping centre understood as a centre of community life and a relevant institution in society [27]. One of the most significant symptoms of this phenomenon is the conversion to new non-commercial uses of old malls. The First Baptist Church at the Mall opened since 2006 in Florida (USA) is a case in point [28].

New types of shopping centres have also appeared, such as the strip shopping centre, strip mall, or affinity centre and villages. In parallel, the situation in city centres is marked by what has been configured as a new urban commerce [29], with a mix of typologies where the old-with and without modifications-coexist with new types.

Therefore, the urban landscape is composed in a high percentage by elements, isolated or together, of spaces and buildings that are, or have been, destined to trade and exchange. The main objective of 
the present work is to analyse some commercial typologies that exist in historical urban areas and its relationship with the urban landscape and its heritage values.

Demonstrated from several areas of knowledge the essential role of trade in urban areas, both in the past and in the present, this work also analyses how monumental building typologies whose original function may have been commercial or not constitute essential elements of the current historical city. How the historic buildings and their uses that are part of the commercial urban landscape, create and modify it, but also preserve it as it acts as a cultural element of prestige and attraction of the consumer.

\section{Line of Work and Methodology}

This research is developed under a working line which is based on the relationship between the preservation of historic urban areas and their adaptation to the needs that contemporary society demands of them in order to continue living within them [30-34]. In particular, we focus on urban commerce, as it is one of the elements that have received the least monographic attention relative to the primary focuses of preservation and the scientific knowledge of cultural heritage. There is a large amount of literature devoted to the management of commercial activity in urban areas, which in some cases looks at areas with heritage protection, but generally concentrates on the analysis of economic and management aspects [29,35-41], lacking a deep cultural heritage-oriented approach.

The research method used is based on the empirical study of the object of attention, from the perspective of the visual analysis of the urban landscape. The choice to identify and evaluate the results of the initiatives developed or under development from the visual analysis of the urban landscape is motivated by the specific point of view of the art historian. This is always based on the vision, analysis, and interpretation of the image, what it contains, and how it is perceived-a reading that is integral, allowing one to simultaneously analyze the physical and the functional, the tangible and the intangible.

Research is an integral part of a doctoral thesis entitled 'Commerce and Cultural Heritage: Management strategies and actions carried out in historic urban areas' [42] which objective is to analyse the role of the commercial activity in historic urban areas in relation to the preservation of their heritage values. Entities, models and cities from five continents have been investigated, especially from the United States, Cuba, the Netherlands, the United Kingdom, France, Belgium and Spain.

The present work includes different cases of study. The approximation to the historic development of urban commerce is based on United States and Western Europe experience. The results of the field work are based on four European cities: Madrid (Spain), Porto (Portugal), Norwich (UK) and Leiden (Netherlands). All of them have historic urban areas protected in which urban commerce play an important role. Madrid is the capital of Spain and has a population of around 3,222,000 [43]; Porto is the second most important city in Portugal and its population is around 214,500 [44]; Norwich has a population around 140,300 [45] and is 'one of the five fastest growing cities in the UK' [46] (p. 18); Leiden is one of the most important cities in South Holland province and has a population around 124,400 [47].

The following section presents the analysis of the mentioned cases and the preliminary results extracted. The analysis is mainly focused on elements that allow identifying some of the trends and transformations that commercial activity is experiencing in urban centres. Firstly, commercial formats that are being developed in order to move commercial offer from the peripheries to urban centres. Secondly, new commercial formats that establish a dialogue with the heritage values of the urban landscape, using them as a resource of attraction and differentiation for increasing their clientele.

\section{Analysis and Preliminary Results}

The traditional commercial areas of urban centres are considered commercial laboratories, especially in large cities, where they try out and filter tendencies that later expand into other small cities and towns [29].

The analysis of the urban landscape shows that, at present, there is a convergent tendency of commercial typologies that includes the adaptation to urban centres of formats typical of the 
peripheries, such as supermarkets or the urban stores of companies whose premises were formally only installed in peripheral commercial areas (Figure 1). Due to this, companies have developed formats in which the concept is adapted to the requirements or limitations of the urban regulations in protected areas and the characteristics of existing commercial premises. This process has contributed to the disappearance of local supermarkets, which cannot compete on prices with those belonging to large groups, which can now also operate as franchises.

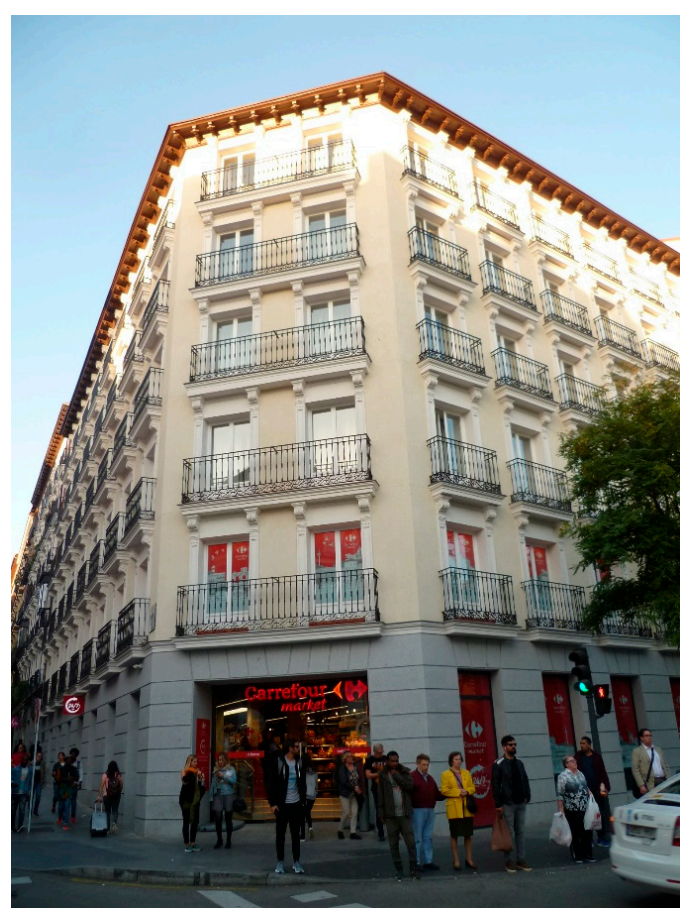

(a)

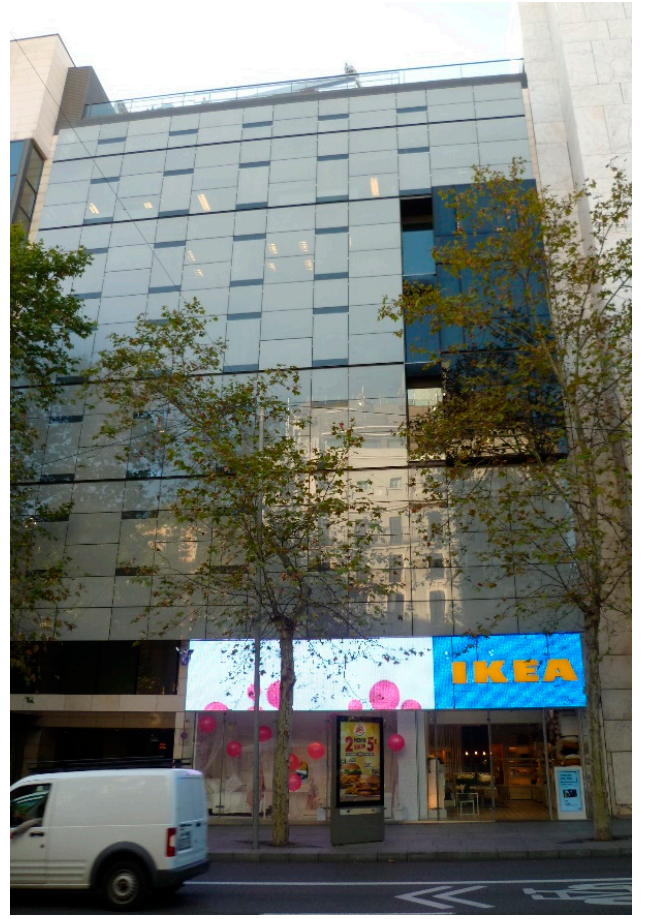

(c)

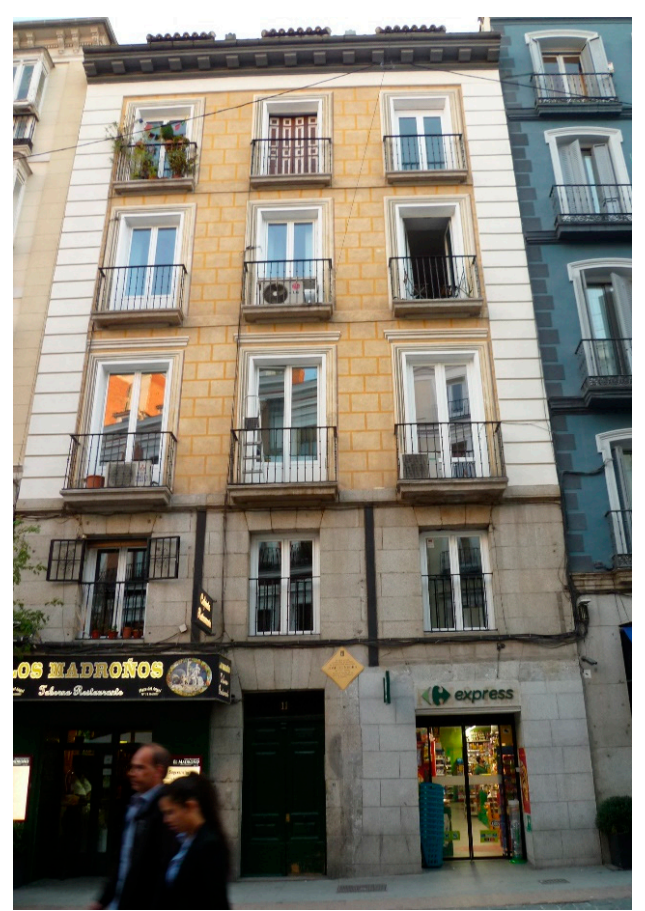

(b)

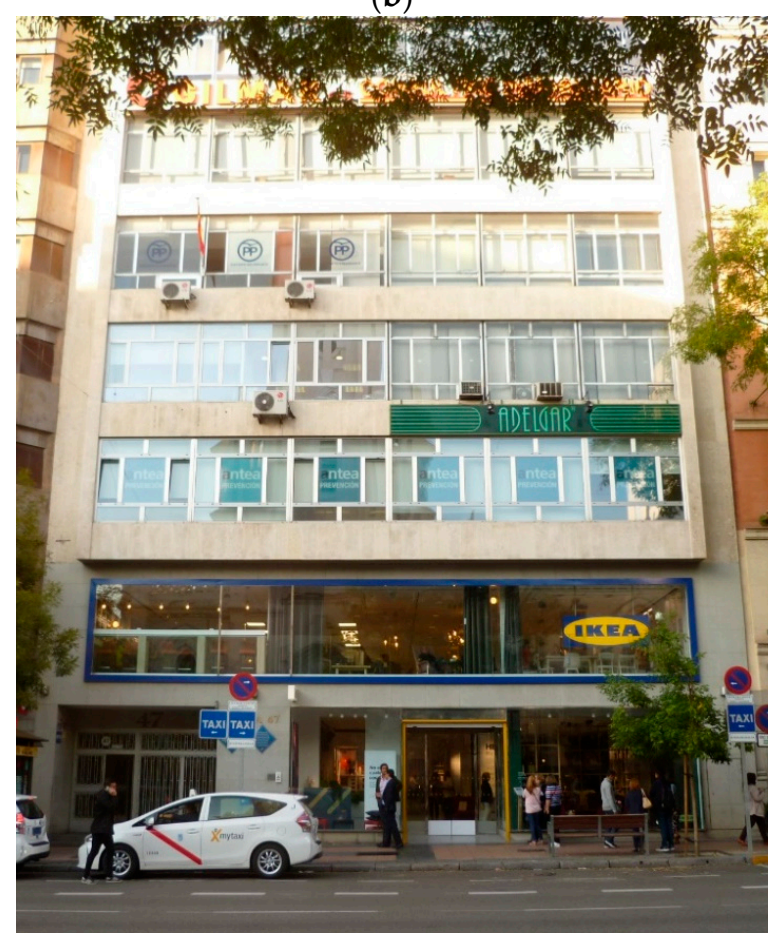

(d)

Figure 1. (a,b) Proximity formats of the Carrefour supermarket chain (Carrefour Market and Carrefour Express). (c,d) Urban pilot stores of the Ikea chain. All images come from the city of Madrid (Spain) [48]. Source: Mónica López, 2018. 
At present, we no longer only speak of a traditional supply trade for urban commerce, but also associate it with innovative business profiles that are going to develop their activities in permanent and non-permanent physical spaces, constituting themselves as essential actors in the current urban landscape of historical urban centres.

The rise of electronic commerce, or the simple possibility of purchasing from a computer, has forced retail outlets to change strategies in their stores. They must now make it an experience to visit their stores so that customers will want to go to them [49].

We speak of an attraction trade whose clientele transcends the residents of the neighbourhood, its extent depending, more or less, on the function that the city represents within the territory, the attraction capacity of the store owners, and the character and state of conservation of the cultural heritage of the urban centre.

A formula that is gaining prominence is that of the shared space, where several business people share the expenses of a single place in which each one has an individualized store space. This is the version of commercial activity known as the co-working premises, a concept associated with offices and professional activities that providing services rather than selling products.

In the search for space optimization and cost reduction, multifunction spaces house different uses or services depending on the hour or day. There are also spaces that house different functions simultaneously, usually selling clothing and decoration associated with cafeterias, to which can be added other functions, such as hairdressing, massage, or sale of art works.

In the ephemeral urban landscape produced by commercial exchange activity, a new format has appeared: pop-up stores/retail/shops. These are installations that appear and disappear, directed not at sales, but to the promotion and branding of the company and/or of certain products. They seek to convey a goal that is not simply to sell a product, but to sell a concept and provide an exclusive experience, thereby attracting the customer to the brand by directing them to both its online store and its digital communication channels.

Another ephemeral manifestation of creation or intervention in the landscape is the punctuated event format similar to a market, but spread or developed over a specific urban area. These actions provide the possibility of buying and selling products to complete cultural programs generated around commercial activity, which is always the main reason for the existence of these events. Sometimes only shops installed in physical stores in the area can participate, which display their products on the street, or the events can be open to other companies to install pop-ups or have temporary displays.

The businesses that represent new urban commerce coexist with other older businesses, these, in many cases, tending to disappear for different reasons: disappearance of shop owners without generational relief, exhaustion of the concept of a particular trade, changes in the commercial dynamics of the street or area where the store is located, regulatory changes, or the disappearance of its clientele. There are also cases in which historic stores are kept alive and accommodate the demands of the current consumer without changing their focus. Another traditional method that is maintained is that of the craftsperson who has a shop-workshop where they make and sell their products.

A historical commercial typology that is maintained is that of the market, whether it be a stable market housed in a building (Figure 2) or an installation erected for that purpose (Figure 3a,b), or in a temporary format (usually of a weekly nature) (Figure 4a,b). However, a substantial number of the markets housed in buildings have being restructured in order to revitalize them and also update its offer (Figure $5 \mathrm{a}-\mathrm{c}$ ) or turn them into a tourist attraction (Figure $5 \mathrm{~d}$ ). 


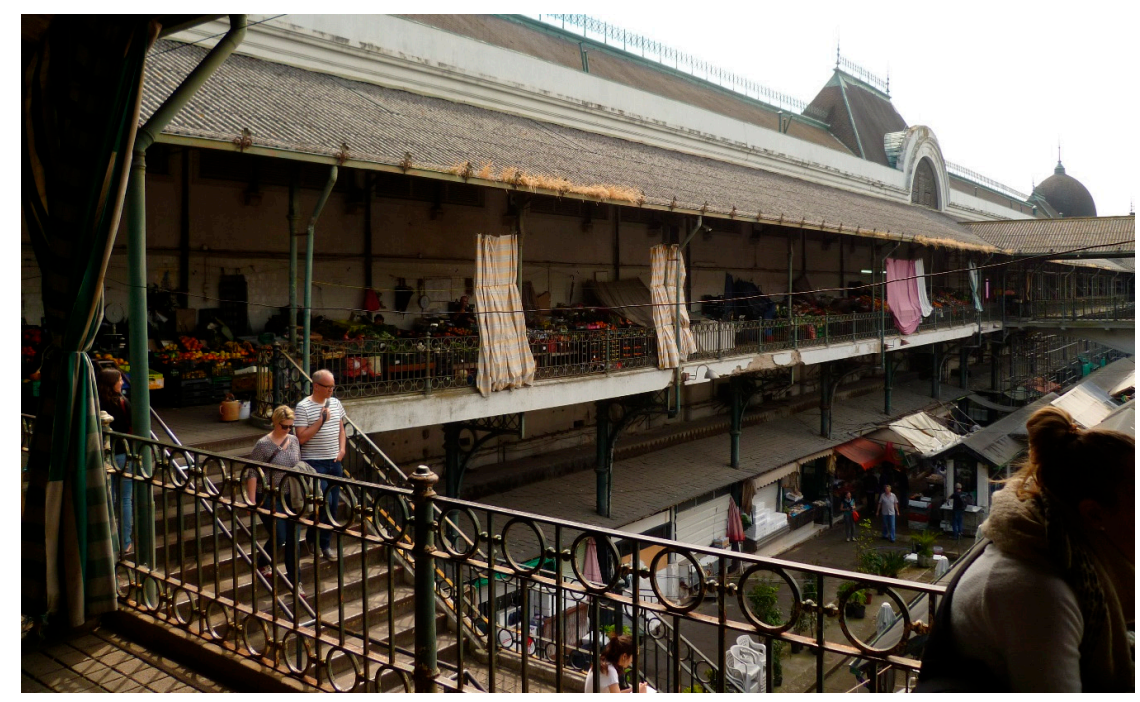

Figure 2. Bolhao Market Porto, Portugal. Source: Mónica López, 2017.

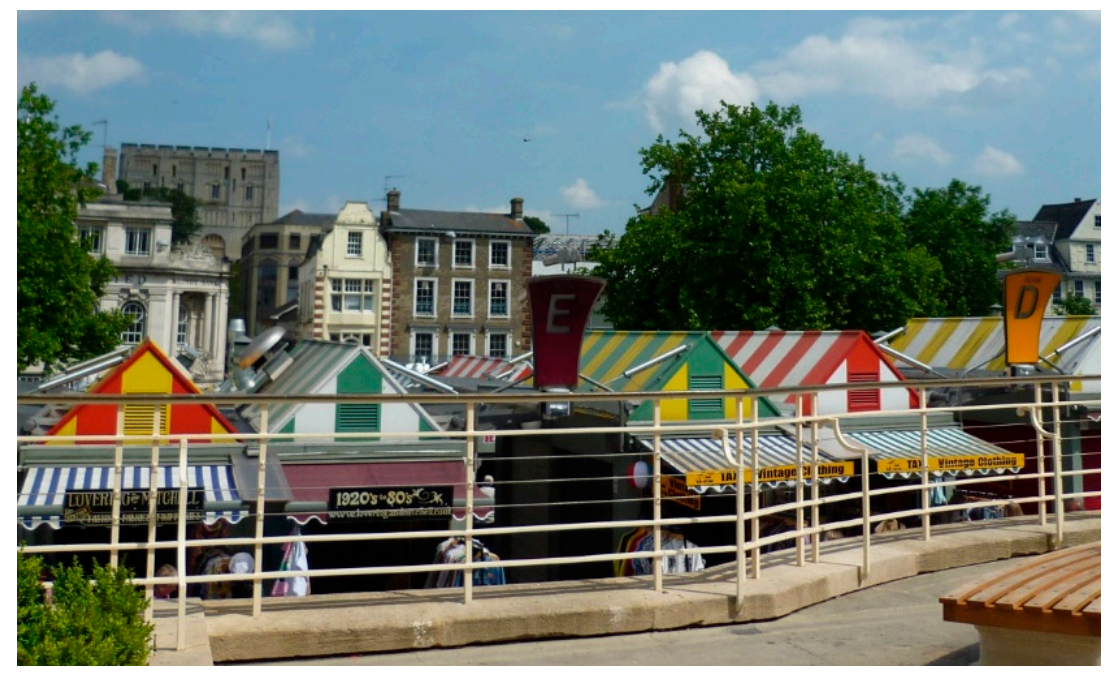

(a)

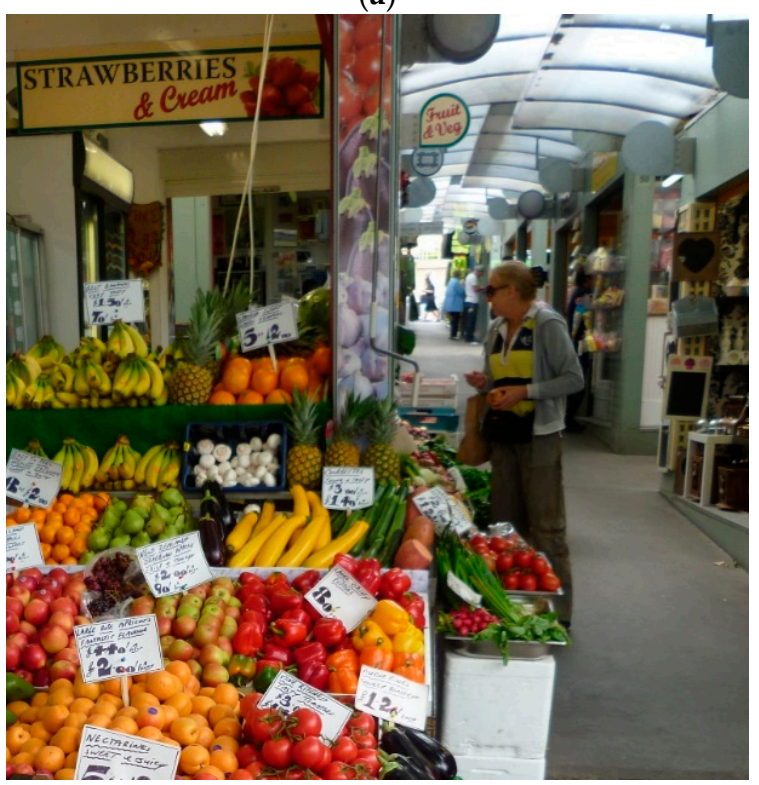

(b)

Figure 3. (a,b) Norwich Market, UK. Source: Mónica López, 2011. 


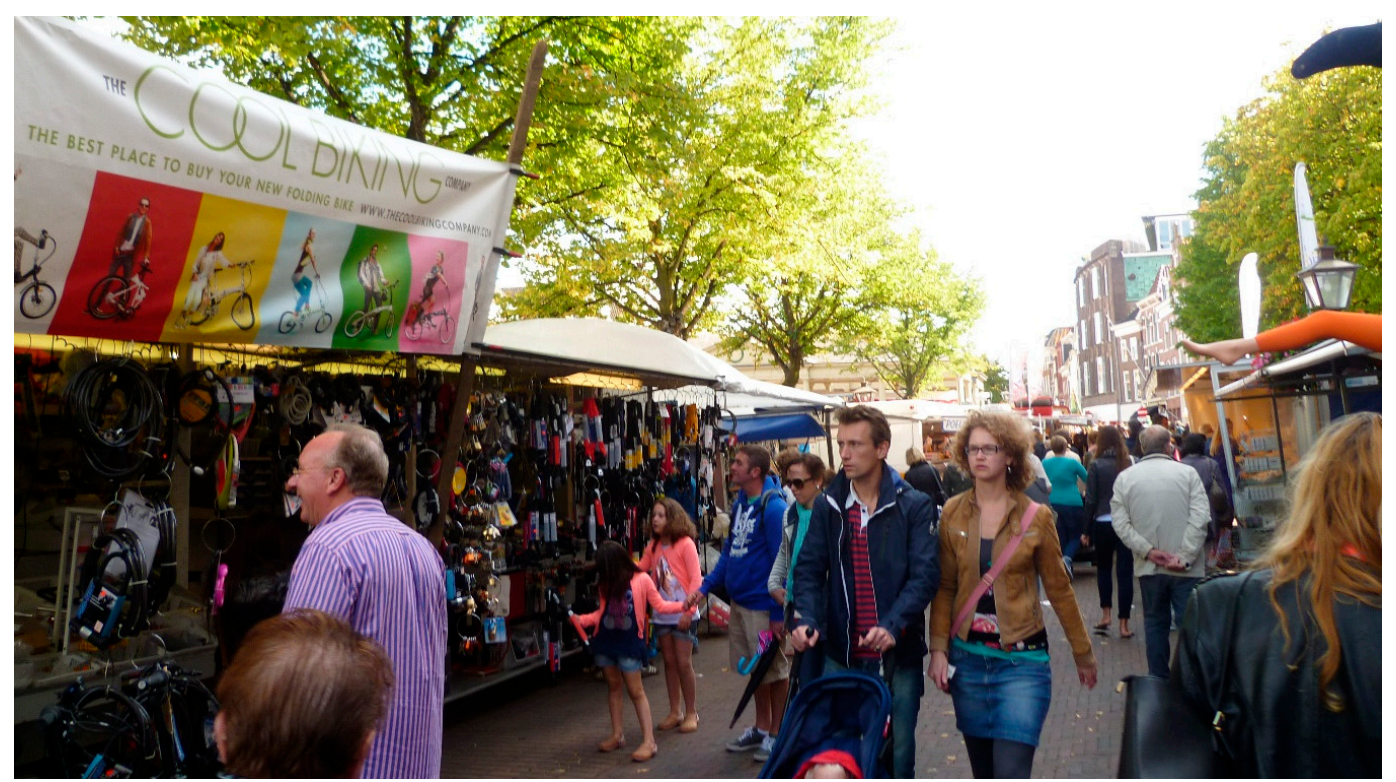

(a)

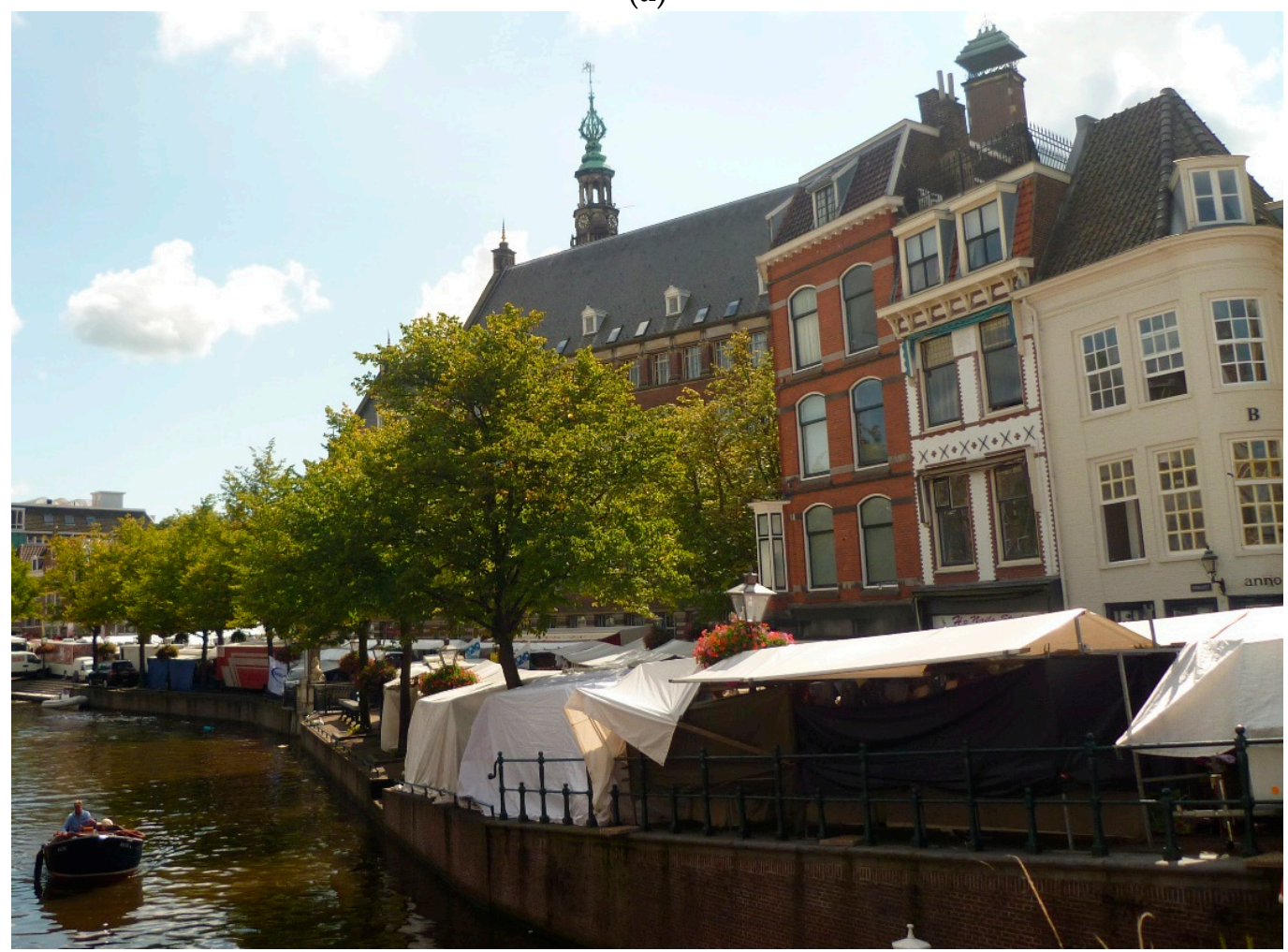

(b)

Figure 4. (a,b) Saturday market in Leiden, The Netherlands. Source: Mónica López, 2014. 


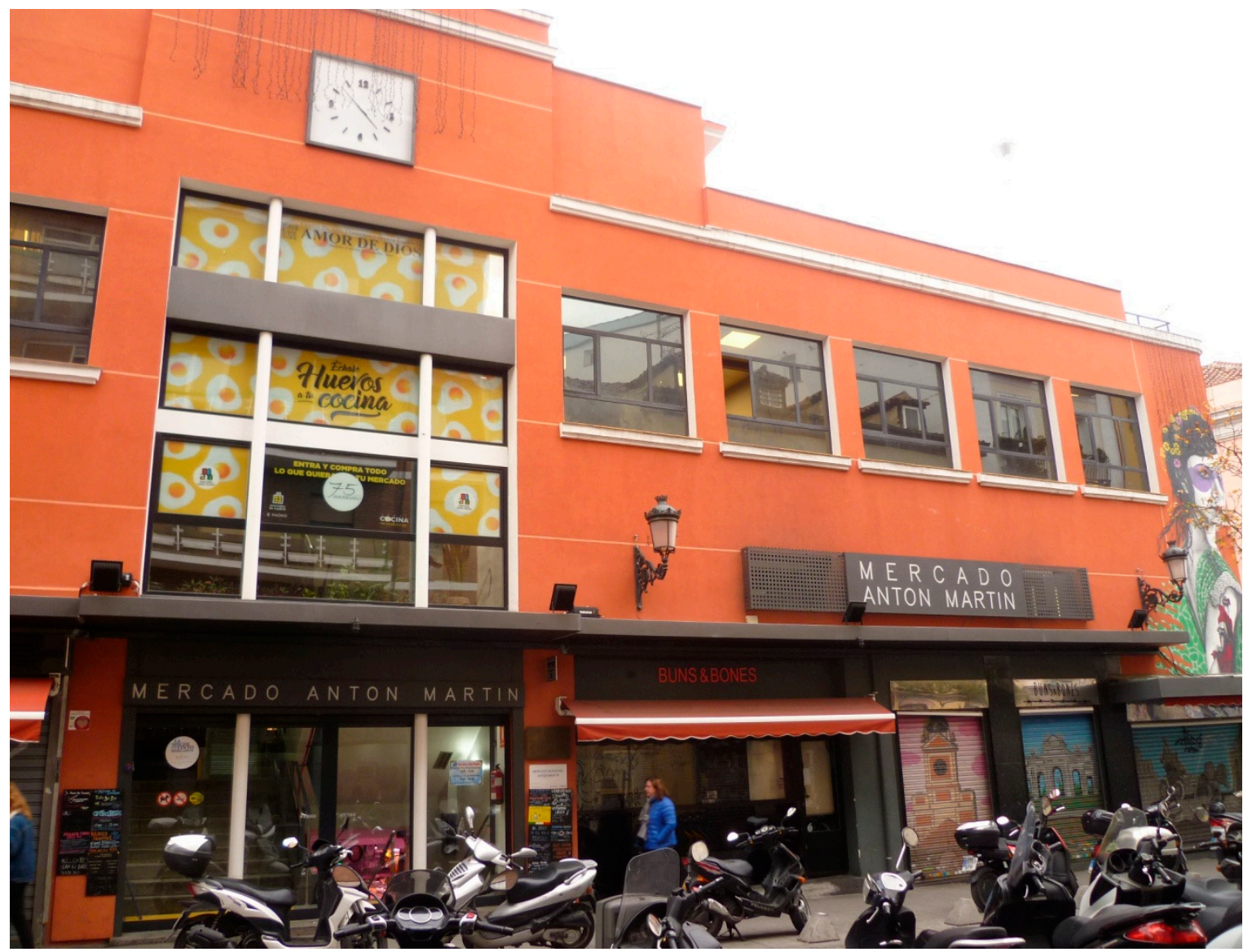

(a)

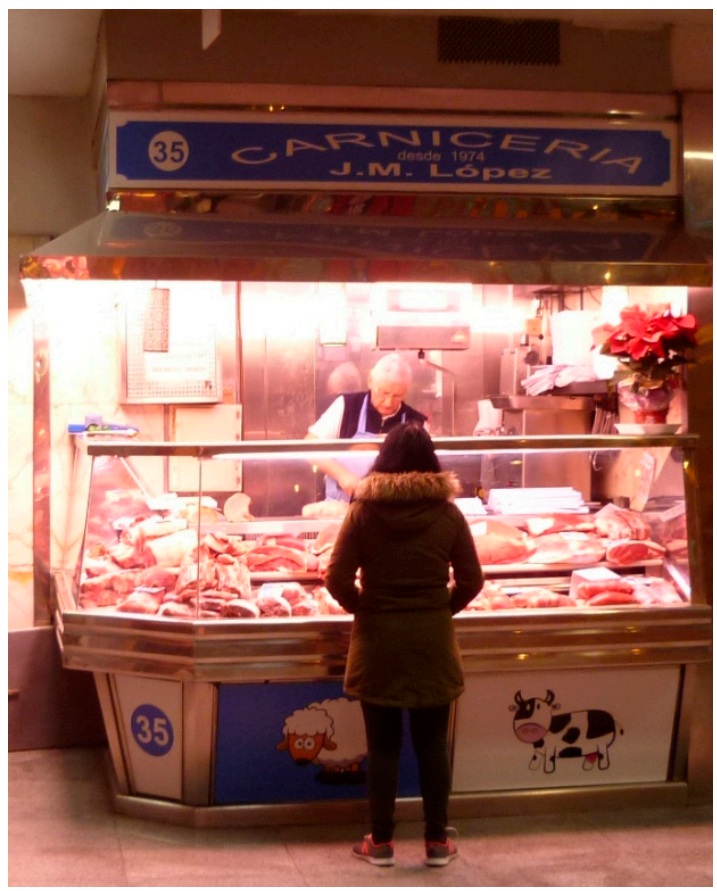

(b)

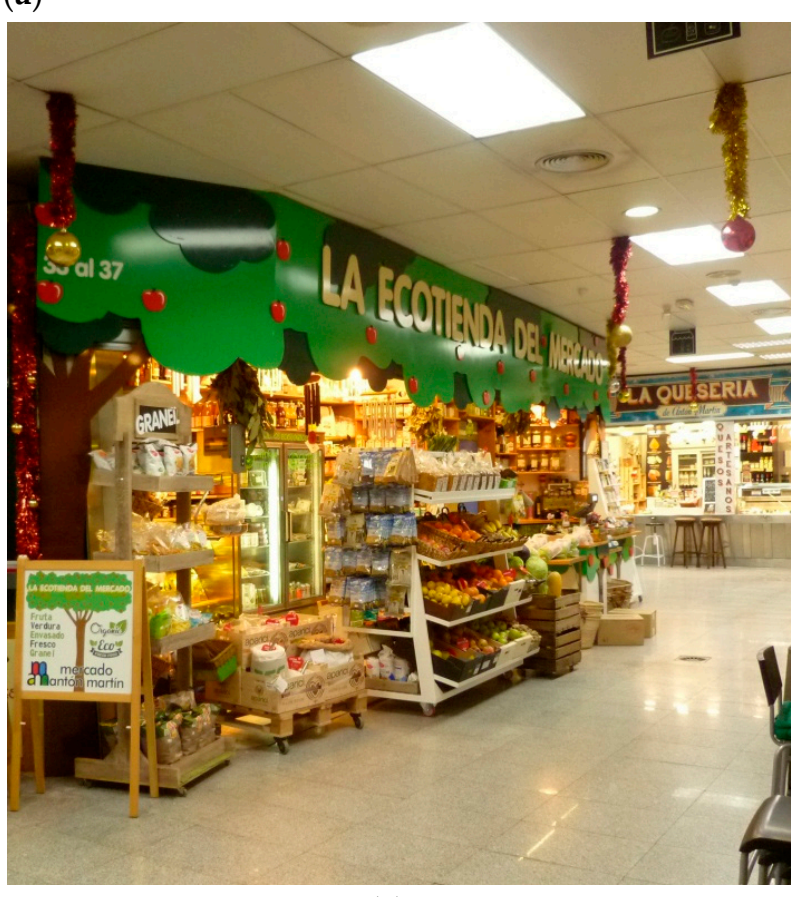

(c)

Figure 5. Cont. 


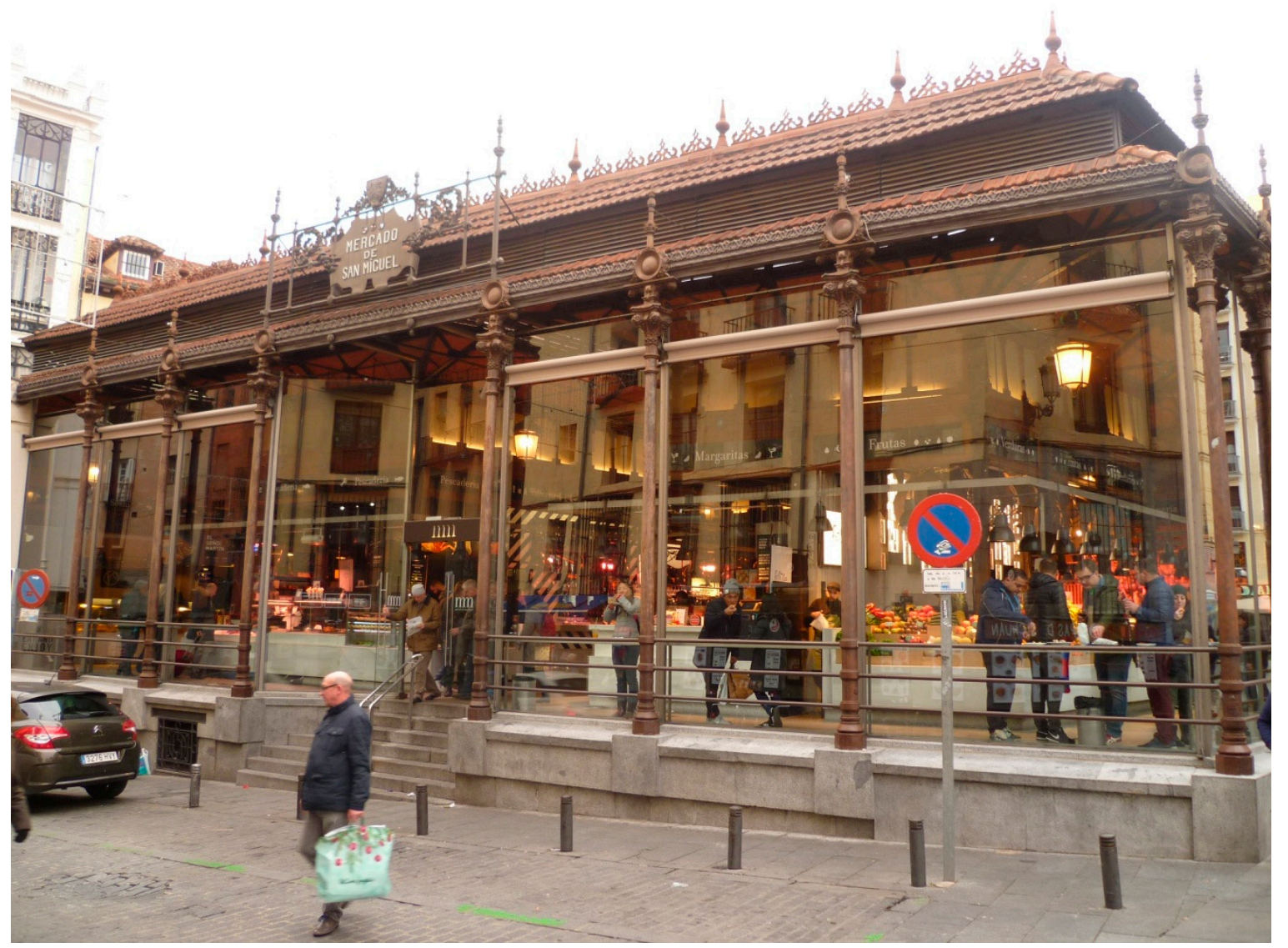

(d)

Figure 5. (a-c) San Antón Market and (d) San Miguel Market, Madrid (Spain). Source: Mónica López, 2018.

Most of the new formats of urban commerce respond to the concept of a city that has been established since the end of the 20th century, where the festive, the immaterial, the playful, and the cultural, and their combinations with commercial leisure, take on greater prominence [25].

Added to this are the implications of the translation of business management techniques to urban management, from which city marketing has emerged [50]. Cities develop value creation strategies in which cultural heritage emerges as a differentiation resource that is linked to its ability to attract visitors [51], strongly associated with cultural tourism, but also with the attraction of other economic activities, such as commercial activities.

This power to attract visitors exerted by heritage is linked with concepts that are going to become hegemonic in the 21st century: the emotional and the sensory [52], which are characterizing present and future trends of marketing and branding; and also experience, which guides the tourism and luxury industries, "two of the most powerful engines of the planetary economy" [53] (p. 193).

The clearest case of using the historic urban landscape as a scenario that strengthens and multiplies the brand values that companies want to transmit is found in the ephemeral formats we have discussed. For example, this is the case of the installation of a pop-up of the company Custo Barcelona in one of the buildings that is part of the World Heritage Works of Antoni Gaudí [54-56].

Frequently, these ephemeral formats are promoted and organized by groups of traders who are located in the same urban area (e.g., a neighbourhood, group of streets, or an individual street) with the aim of attracting potential customers of their businesses. This is the case of the so-called Market of the Frogs (Figure 6a,b), organized on the first Saturday of each month by the Association of Merchants of the Barrio de Las Letras in the city of Madrid (Spain). 


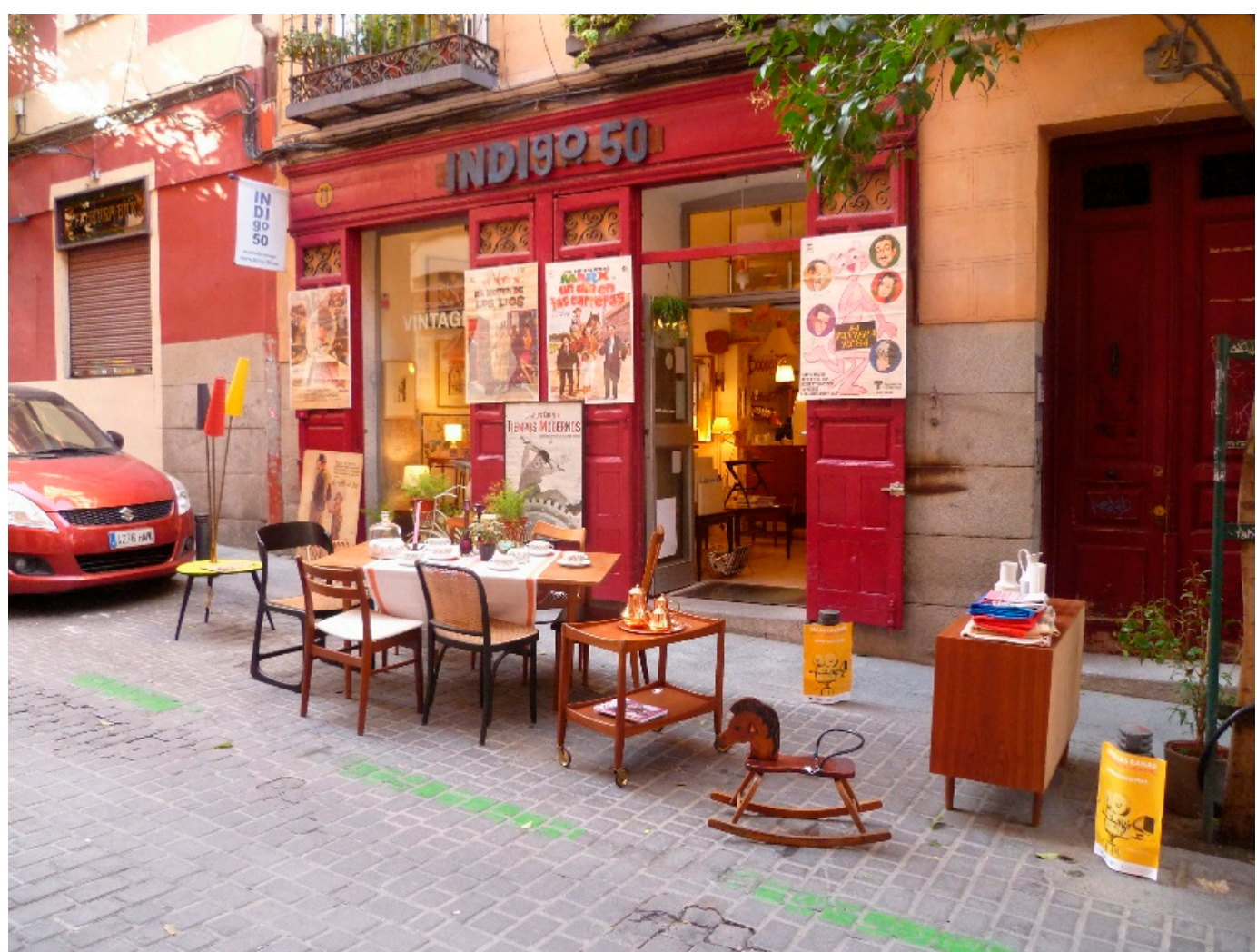

(a)

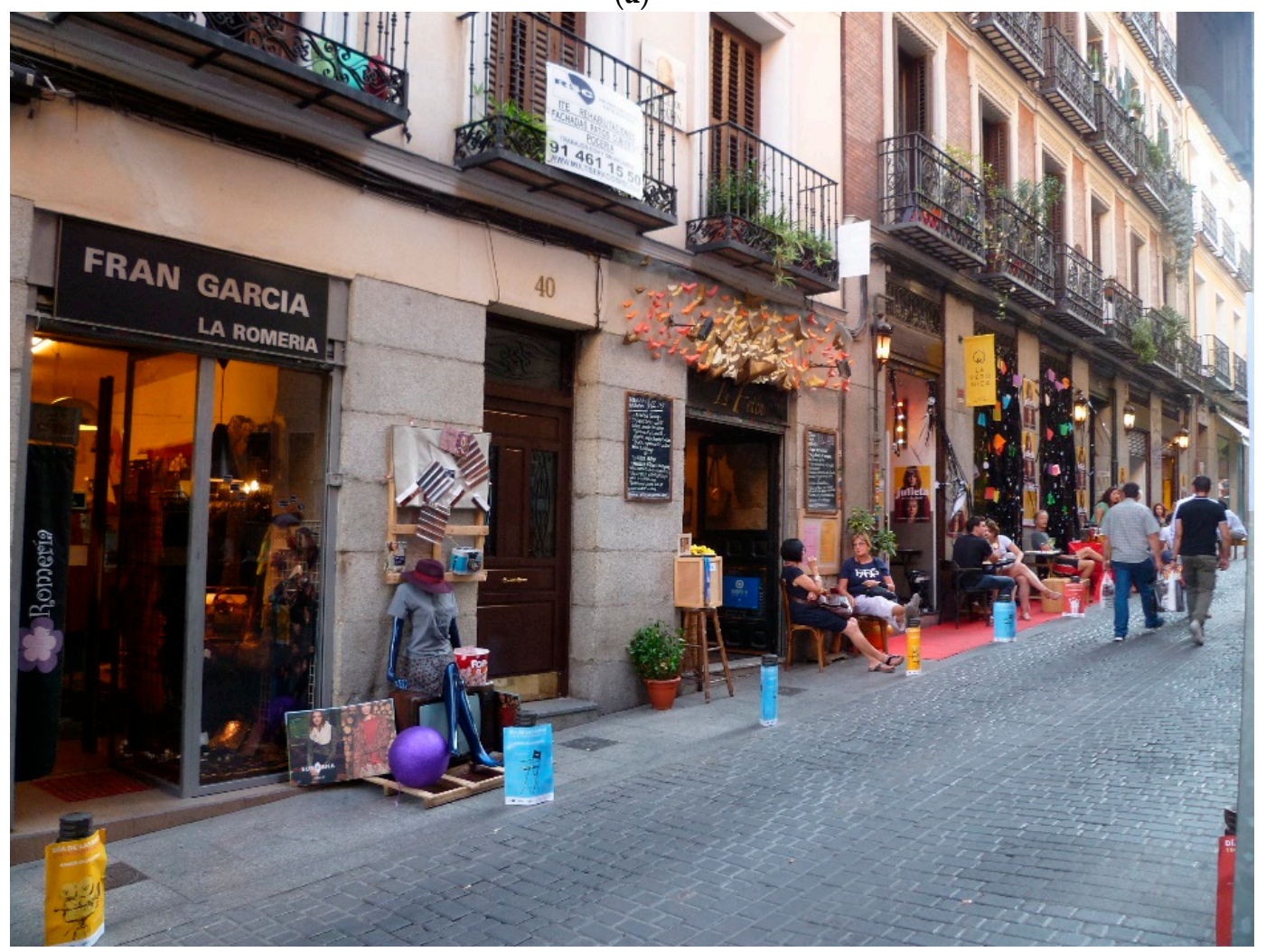

(b)

Figure 6. (a,b) Market of the Frogs, Barrio de Las Letras in Madrid (Spain). Source: Mónica López, 2016.

These uses of heritage value take place in commercial premises. Mainly in the case of the exteriors, the maintenance of the defining elements of the premises' facades may be motivated by the 
requirements of heritage protection regulations. These usually contain guidelines regarding materials, designs, colours, and decorative elements. However, maintenance can also occur, as is usual for the case of the interiors of the premises; a new company recovers historical elements associated with its trade for the design of its premises by maintaining existing elements, or deciding not to part with elements associated with its own activity throughout its history.

These cases are also significant for the recognition of heritage values related to the commercial activity, through the elements associated with it, by its direct participants. In addition to the provision of value, store owners contribute to the preservation process of cultural heritage through the identification of the heritage elements, the realization of intervention projects, and the diffusion of these and of the knowledge related to the commercial activity itself.

\section{Discussion, Conclusions and Future Works}

The previous analysis allows extracting relevant information about commercial typologies in historical urban areas. It is necessary to remark that trade is a living activity, as are the people who give it meaning, who generate the flow of goods, ideas, and of people who have to pass through the inherited urban fabric. The commercial urban landscape of historic urban areas is a mixture of formats, sizes, and proposals, where hundred-year-old establishments coexist with newly created ones, stores anchored in the past with the avant-garde, stable points of sale with the ephemeral, local shops to supply residents from the neighbourhood with other attractions for clientele that originate from the same city or visitors from another country. All this is in constant movement and susceptible to change.

Given its nature as a private economic activity, trade changes, evolves, and transforms according to the needs of the market and society, or it disappears. This makes it, therefore, difficult to approach from the point of view of protection of cultural heritage, both of its physical and immaterial elements.

Commerce is also a part of the heritage value of protected cities, as it is one of the defining functions of an urban area. From the point of view of the preservation of urban protected areas, it is necessary to unite with this the preservation of the commercial function itself, both for its intrinsic values and for its role in the balance of the urban ecosystem, especially in relation to the establishment of the resident population.

In this sense, it can be said that the substitution of one trade for another is good news because the premises retains a commercial function despite the closure of the previous business. Detailed analyses of the urban landscape frequently reveal periodic changes in terms of products and brands, but globally the use of the premises and the flow of people they generate are maintained.

The new formats of local supermarkets are also helping to recover the service of supplying necessities that has been badly damaged by the expansion of land use in the suburbs and the disappearance of food stores in most central areas. These types of establishments also offer extra services, such as home delivery, for which they have vehicles adapted to the historical layout of the city. It is a clear example of how trade is essential to maintaining the residential character of these areas.

Trade is part of the urban landscape, creating it and modifying it, but also preserving it. At present, the predominant tendencies in promotion and sales strategies look to elements that are contained in cultural heritage, in general, and in historical urban landscapes, in particular. This favours the idea that, in the difficult equation between preservation and destruction, urban commerce is an ally of preservation, despite the complex historical relationship between merchants and administrations in their management of protected areas.

As is already commented at the introduction of this work, there is a close relationship between the urban phenomenon and commercial activity throughout history. Therefore, is possible to affirm that trade is an essential element of the city and its urban landscape. For this reason, the historical research of urban commercial activity provides essential information on the configuration of cities, in general, and of protected urban areas, in particular. It also provides information to understand at present the relationship between commercial activity and urban space. 
The transcendence of commercial activity in the historical evolution of the city is reflected in the presence of elements linked to it in the cultural heritage currently existing in urban settlements. The relationship of feedback between stores and markets and the influx of people is manifested throughout the history of the city, and is reflected both in the names of many streets and squares, and in the fact that various commercial uses are currently maintained in certain spaces that have been hosting these activities for decades, even centuries.

It is common that among the elements of urban cultural heritage preserved in many cities today, a direct relationship with their commercial past can be established. In some cases, buildings or other architectural, sculptural, or pictorial elements are preserved specifically because they are associated with the commercial boom in which they appeared. In other cases, it is because the urban framework preserves developments or reforms that have occurred as a result of the impact of commercial activity. There are also cases in which manifestations of intangible heritage are linked to commercial events or the production of certain goods and services that have fuelled an economic boom associated with their trade.

This work is part of a larger project and presents initial analysis and results which are supported by empirical evidences. As future work, an extensive analysis of the role of commercial activity in historic urban areas in relation to the preservation of their heritage values will soon be published in book format.

Author Contributions: Conceptualization, methodology, validation, M.G.M. and M.L.S.; investigation, resources, M.L.S.; writing—original draft preparation, writing—review and editing, M.G.M. and M.L.S.; supervision, M.G.M.; project administration, M.G.M.; funding acquisition, M.G.M. and M.L.S.

Funding: This research was funded by the Ministerio de Economía y Competitividad, Gobierno de España, grant number HAR2014-58151-R “Análisis del impacto de estrategias de regeneración urbana sobre la conservación del patrimonio cultural de zonas industriales históricas".

Conflicts of Interest: The authors declare no conflict of interest. The funders had no role in the design of the study; in the collection, analyses, or interpretation of data; in the writing of the manuscript, or in the decision to publish the results.

\section{References}

1. Choay, F. L'Allégorie du Patrimoine; Seuil: Paris, France, 1992; ISBN 9782020143929.

2. ICOMOS. Xi'an Declaration on the Conservation of the Setting of Heritage Structures, Sites and Areas. Declaration Adopted in Xi'an, China, by the 15th General Assembly of ICOMOS on 21 October 2005 (Final Version-22.10.2005). Available online: https://www.icomos.org/xian2005/xian-declaration.htm (accessed on 1 October 2018).

3. UNESCO. Recommendation on the Historic Urban Landscape, Including a Glossary of Definitions. In Proceedings of the 36th Session Records of the General Conference, Paris, France, 25 October-10 November 2011; UNESCO: Paris, France, 2012; pp. 50-55.

4. Franchetti Pardo, V. La Ciudad: El Nacimiento de la Ciudad en Occidente; Tikal: Madrid, Spain, 2011.

5. Journaux, A. La Géographie et le Commerce. In Histoire du Commerce, Livre Premier La Terre et les Hommes; Jacques Lacour-Gayet; SPDI: Paris, France, 1950.

6. Delfante, C. Grande Histoire de la Ville de la Mésopotamie aux Etats-Unis; Armand Colin: Paris, France, 1997; ISBN 9782200014742.

7. Pirenne, H. The Stages in the Social History of Capitalism. Am. Hist. Rev. 1914, 19, 494-515. [CrossRef]

8. Boulnois, L. La Route de la Soie; Arthaud, Signes des Temps: Paris, France, 1963.

9. Godelier, M. L'Idéel et le Matériel: Pensée, Économies, Sociétés; Fayard: Paris, France, 1984; ISBN 9782213653051.

10. Franchetti Pardo, V. Città, Architetture, Maestranze tra Tarda Antichità ed età Moderna; Editoriale Jaca Book: Milan, Italy, 2001; ISBN 9788816405493.

11. Gates, C. Ancient Cities: The Archaeology of Urban Life in the Ancient Near East and Egypt, Greece and Roma; Routledge: London, UK; New York, NY, USA, 2003; ISBN 9780415018951.

12. De Seta, C. Citta, Paesaggi e Divagazioni tra Passato e Futuro; Rizzoli: Milan, Italy, 2016; ISBN 9788858685112. 
13. Mumford, L. The City in History: Its Origins, Its Transformations, and Its Prospects; Harcourt, Brace and World: New York, NY, USA, 1961.

14. Bollerey, F. La plaza: Visiones de multitud y soledad. Ábaco Rev. Cult. Cienc. Soc. 2009, 60-61, 50-65.

15. Augenti, A. Città e Porti Dall'antichità al Medioevo; Carocci: Roma, Italy, 2010; ISBN 9788843052783.

16. De Seta, C. Ritratti di Città. Dal Rinascimento al Secolo XVIII; Einaudi: Turin, Italy, 2011; ISBN 9788806207311.

17. Rico, J.C. La Exposición Comercial: Tiendas y Escaparatismo, Stands y Ferias, Grandes Almacenes y Superficies; Trea: Gijón, Spain, 2005; ISBN 9788497041812.

18. Serrano Sáseta, R. Los orígenes comerciales del fenómeno de la desmaterialización de la fachada en la arquitectura moderna: Transparencia y luz eléctrica. Rev. Eur. Investig. Arquit. (REIA) 2014, 2, 163-180.

19. Benevolo, L. Storia Dell'architettura Moderna; G. Laterza: Bari, Italy, 1960.

20. Harvey, D. Paris, Capital of Modernity; Routledge: New York, NY, USA, 2003; ISBN 9780415952200.

21. Capel, H. La Morfología de las Ciudades. II. Aedes Facere: Técnica, Cultural y Clase Social en la Construcción de Edificios; Ediciones del Serbal: Barcelona, Spain, 2005; ISBN 9788476283554.

22. Castells, M. La Question Urbaine; François Maspéro: Paris, France, 1972.

23. Hall, P. Cities of Tomorrow: An Intellectual History of Urban Planning and Design in the Twentieth Century; Blackwell: Oxford, UK; New York, NY, USA, 1988; ISBN 9780631134442.

24. Bruegmann, R. Sprawl: A Compact History; University of Chicago Press: Chicago, IL, USA, 2005; ISBN 9780226076911.

25. Lipovetsky, G.; Serroy, J. L'esthétisation du Monde: Vivre à L'âge du Capitalisme Artiste; Gallimard: Paris, France, 2013; ISBN 9782070140794.

26. Underhill, P. El Placer de Comprar; Gestión 2000: Barcelona, Spain, 2007; ISBN 9788496612679.

27. Cohen, L. From Town Center to Shopping Center: The Reconfiguration of Community Marketplaces in Postwar America. Am. Hist. Rev. 1996, 101, 1050-1081. [CrossRef]

28. Church in the Mall. Available online: http:/ / churchatthemall.com/history/ (accessed on 24 August 2015).

29. Rovira Lara, A.; Forés Marzá, D.; Hernández Samper, C. Gestión Innovadora de Centros Comerciales Urbanos: Modelos y Experiencias; Trea: Gijón, Spain, 2012; ISBN 9788497046510.

30. Larkham, P.J. Conservation and the City; Routledge: London, UK; New York, NY, USA, 1996; ISBN 9780415079488.

31. Kovács, Z. Social sustainability of historic districts: The East-Central European experience. In Proceedings of the UNESCO International Seminar: Balanced Urban Revitalization for Social Cohesion and Heritage Conservation, Beijing, China, 21-23 January 2007; UNESCO: Paris, France, 2008; pp. 55-72.

32. Mason, R.F. Preservation Planning in American Cities. Forum J. 2009, 23, 38-44.

33. Bandarin, F.; Van Oers, R. The Historic Urban Landscape: Managing Heritage in an Urban Century; Wiley-Blackwell: Chichester, UK, 2012. [CrossRef]

34. Ruggles, F. Introduction: The Social and Urban Scale of Heritage. In On Location: Heritage Cities and Sites; Springer: New York, NY, USA, 2012; pp. 1-15. [CrossRef]

35. Molinillo Jiménez, S. Centros Comerciales de Área Urbana: Especial Referencia a las Relaciones con Entidades Laterales. Doctoral Thesis, University of Malaga, Malaga, Spain, 2000.

36. Hoyt, L. The Business Improvement District: An Internationally Diffused Approach for Revitalization. 2004. Available online: http:/ / www.lorlenehoyt.com/yahoo_site_admin/assets/docs/Hoyt_IDA.325174429.pdf (accessed on 12 July 2015).

37. Friesecke, F. Revitalization of Urban Areas through Business Improvement Districts (BIDs)-Trends and Expectations for Shrinking Cities. In Proceedings of the 5th FIG Regional Conference on Promoting Land Administration and Good Governance, Accra, Ghana, 8-11 March 2006; pp. 1-18.

38. Becker, C. Government without Government: Alternatives to Market and Government Failure. Doctoral Dissertation, Hamline University, Saint Paul, MN, USA, 2008.

39. Cook, I.R. Private sector involvement in urban governance: The case of Business Improvement Districts and Town Centre Management partnerships in England. Geoforum 2009, 40, 930-940. [CrossRef]

40. Coca-Stefaniak, J.A. The Evolving Nature of Town Centre Management Internationally and My Advocacy for a Strategic Global-Local Approach to Practice and Research in This Profession. Doctoral Thesis, Middlesex University, London, UK, 2012. 
41. Tejada Barrenetxea, S. La Colaboración Público Privada Entre Administraciones y Comerciantes, Clave para la Dinamización del Comercio Urbano. Planteamiento de un Nuevo Modelo. Doctoral Thesis, University of the Basque Country, Leioa, Spain, 2016.

42. López Sánchez, M. Comercio y Patrimonio Cultural: Estrategias de Gestión y Acciones Desarrolladas en Áreas Urbanas Protegidas. Doctoral Thesis, University of Murcia, Murcia, Spain, 2018.

43. Ayuntamiento de Madrid. Informe Padrón Municipal de Habitantes-Ciudad de Madrid (1 de enero de 2018); Ayuntamiento de Madrid: Madrid, Spain, 2018; Available online: https://www.madrid.es/ UnidadesDescentralizadas/UDCEstadistica/Nuevaweb /Demografíaypoblación/Cifrasdepoblación/ PMH/Informe/Informe_PMH2018.pdf (accessed on 2 October 2018).

44. Instituto Nacional de Estatística, PORDATA. População Residente, Estimativas a 31 de Dezembro 2017. Available online: https://www.pordata.pt/Municipios/Populaçao+residente++estimativas+a+31+de+ Dezembro-120 (accessed on 2 October 2018).

45. Office for National Statistics. Population Estimates for UK, England and Wales, Scotland and Northern Ireland: Mid-2017. Available online: https://www.ons.gov.uk/ peoplepopulationandcommunity/populationandmigration/populationestimates/datasets / populationestimatesforukenglandandwalesscotlandandnorthernireland (accessed on 2 October 2018).

46. New Local Government Network. Key Cities Unlocking Potencial. Available online: https://www. keycities.co.uk/sites/default/files/publications/key-cities-biggest-challenges-report.PDF (accessed on 2 October 2018).

47. Rijksoverheid-Basisregistratie Personen/Gemeente Leiden. Leiden in Cijfers-Aantal Inwoners. 2018. Available online: https:/ / leiden.buurtmonitor.nl/jive?report=start (accessed on 2 October 2018).

48. Valero, M. Ikea usa España como laboratorio mundial: "Exportaremos su modelo a Tokio o NY", Interview with Jesper Brodin, Ikea CEO, 11.10.2018. El Confidencial. Available online: https:/ / www.elconfidencial. com/empresas/2018-10-11/ikea-usa-espana-laboratorio-pruebas_1628520/ (accessed on 11 October 2018).

49. Gobé, M. Emotional Branding: The New Paradigm for Connecting Brands to People; Allworth Press: New York, NY, USA, 2001; ISBN 9781581150780.

50. Kotler, P.; Haider, D.H.; Rein, I.J. Marketing Places: Attracting Investment, Industry, and Tourism to Cities, States, and Nations; Free Press, Maxwell Macmillan: New York, NY, USA; Toronto, ON, Canada, 1993; ISBN 9780029175965.

51. de Elizagarate, V. Marketing de Ciudades: Estrategias para el Desarrollo de Ciudades Atractivas y Competitivas en un Mundo Global; Pirámide, ESIC: Madrid, Spain, 2008; ISBN 9788436822045.

52. Stalman, A. Brandoffon: El Branding del Futuro; Gestión 2000: Barcelona, Spain, 2014; ISBN 9788498753615.

53. Michaud, Y. Le Nouveau Luxe: Expériences, Arrogance, Authenticité; Stock: Paris, France, 2013; ISBN 9782234072749.

54. UNESCO World Heritage List. Works of Antoni Gaudí. Available online: https://whc.unesco.org/en/list/ 320 (accessed on 25 September 2018).

55. SeVExAhi. Ferias de Moda. Available online: http:/ / sevexahi.blogspot.com.es/2010/12/ferias-de-moda. html (accessed on 25 September 2018).

56. StylersMag. La Pop-Up Vintage Store de Custo Brilla en The Shopping Night Barcelona. Available online: http:/ / www.agente-k.com/la-pop-up-vintage-store-de-custo-brilla-en-the-shoppingnight-barcelona/ (accessed on 25 September 2018).

(C) 2019 by the authors. Licensee MDPI, Basel, Switzerland. This article is an open access article distributed under the terms and conditions of the Creative Commons Attribution (CC BY) license (http://creativecommons.org/licenses/by/4.0/). 